\title{
Contribution of fruit, vegetables, whole cereals, and legumes to total fibre intake in adult Croatian Dalmatian population
}

\author{
Marijana Matek Sarić1, Marija Ljubičić ${ }^{1,2}$, Ivana Lapčić ${ }^{3}$, and Raquel Pinho Ferreira Guiné \\ ${ }^{1}$ University of Zadar, Department of Health Studies, Zadar \\ ${ }^{2}$ General Hospital Zadar, Department of Paediatrics, Zadar \\ ${ }^{3}$ Medical School Ante Kuzmanića, Zadar \\ ${ }^{4}$ Polytechnic Institute of Viseu, Campus Politécnico, Viseu, Portugal
}

[Received in June 2019; Similarity Check in June 2019; Accepted in June 2020]

\begin{abstract}
There is compelling evidence that fruit, vegetables, whole cereals, and legumes make about $80 \%$ of the total food fibre intake and have a potential to help in the prevention of a number of diseases. The aim of our study was to estimate total fibre intake from consumption of this fibre-rich food, partly reported in our earlier study in Croatian adult population. Current data analysis involved a non-probabilistic sample of 1,034 adult participants from Dalmatia, Croatia who responded to a validated food frequency questionnaire between October 2014 and March 2015. We also analysed the sales data obtained from three shopping centres in the Zadar area (Croatian coast) to establish a list of most frequently bought fruit, vegetables, whole cereals, and legumes and to calculate dietary fibre (DF) intake for each of the top-selling items and conversion factors for each food group. We then used these conversion factors to calculate individual total fibre intake (TFI) in our population. It was $11.4 \mathrm{~g}$ per person per day, which is less than half the recommended dietary requirements. On average, respondents reported to consume one piece of fruit and one meal of vegetables a day, which is less than half the daily recommendation for either. $25.8 \%$ of respondents reported no consumption of whole cereals at all, and only $0.2 \%$ of the population consumed the recommended 3-5 servings of whole grains or legumes a day. We also observed significantly higher consumption of fruit and whole grains/legumes in women than men. Our findings alert to poor dietary fibre intake in Croatian adult population, which is similar to other western countries and points to issues deeply rooted in these economies. However, our findings may be either an over- or under-estimation and need to be verified through longitudinal research on a wider sample using more precise tools.
\end{abstract}

KEY WORDS: conversion factors; dietary fibre; fibre-rich food; recommended dietary requirements; TFI

Increasing evidence suggests that healthy eating with increased consumption of plant-based food prevents chronic diseases $(1,2)$, including non-communicable diseases (NCDs) (3), and has multiple benefits for human health. This effect is related their dietary fibre (DF) content, which includes non-digestible carbohydrates of three or more monomeric units, isolated or synthetic fibres with demonstrated physiological benefits (such as resistant starches), and minor components like lignin in plant cell walls (3-12).

However, diet high in fruit, vegetables, legumes, and cereals is widely recommended not only as a DF source but also as a source of vitamins ( $\mathrm{C}$ and $\mathrm{A}$ in particular), minerals (especially electrolytes), and phytochemicals (especially antioxidants), and it is very difficult to clearly distinguish the health benefits of these components separately $(10,13)$.

Corresponding author: Marijana Matek Sarić, University of Zadar, Department of Health Studies, Splitska 1, 23000 Zadar

E-mail:marsaric@uizd.hr
Even when it comes to total fibre intake (TFI) alone, little has been studied about how each of the these main sources of DF contribute to it and what dietary habits should be changed to achieve the desired TFI of 25-32 $\mathrm{g}$ for women and $30-35 \mathrm{~g}$ for men or alternatively $14 \mathrm{~g}$ of DF/1,000 kcal per day and capita $(3,14)$. This amount changes with gender, age, and recommending organisation, whether it is the United Nations World Health Organization (WHO), Food and Agriculture Organization (FAO), Associated Health Foundation (AHF), American Pediatric Association (APA), American Diabetes Association (ADA), European Food Safety Authority (EFSA), or National Academy of Sciences (Dietary Reference Intakes). A joint WHO/FAO/EFSA recommendation sets the minimum $\mathrm{DF}$ intake to $25 \mathrm{~g} /$ day $(15,16)$.

DF should be obtained from as varied sources as possible, because variety is the golden rule for healthy diet. Eating more fibre-rich food like vegetables, fruit, whole grains, and legumes as principal food fibre sources has been one of the WHO recommendations since 2003 (15). WHO 
recommends eating at least $400 \mathrm{~g}$ of fruit and vegetables a day, more specifically, $200 \mathrm{~g}$ of fruit (at least $2-3$ servings) and $200 \mathrm{~g}$ (2-5 servings) of vegetables (17). The dietary guidelines of the US Whole Grains Council recommend at least $80 \mathrm{~g}$ (3-5 servings) of whole grains a day (17).

\section{PARTICIPANTS AND METHODS}

The first phase of this cross-sectional study included 1,034 Croatian adults between October 2014 and March 2015. Data that we present here were collected as part of a larger survey reported earlier (18) with the help of a validated, quick, and reproducible food frequency questionnaire (FFQ) (19) with 40 items to determine demographic characteristics and average daily and weekly intake of food rich in fibre $(5,20)$. The participants were asked to report their weekly consumption of each item (meal, serving, or portion). Responses (consumption frequency) were numeric values.

We recruited through newspaper advertisements, events at shopping and town centres, and word-of-mouth. The intention was to cover the whole range of ages and education levels among adult urban and rural population of both genders. The participants were informed about the purpose of the study and assured that participation was voluntary and anonymous. Upon signing consent, the participants filled out the survey in cubicles to ensure their privacy. The study was approved by the Human Research Ethics Committee of the General Hospital Zadar. All data were collected and analysed in accordance with the Declaration of Helsinki.

The second phase of the study, conducted in May 2018, involved the analysis of sales data for fruit, vegetables, whole grains, and legumes obtained from three shopping centres in the Zadar area (with a population of 70,000) to determine the top selling items for each food group. Based on DF content per $100 \mathrm{~g}$ of each specific food item established by the United States Department of Agriculture (USDA) National Nutrient Database (21) and portion size, we then calculated total fibre content for each item. Portions and servings were defined according to literature (22-25, 35 ), while meal corresponded to one third or one fifth of all food (serving or portions) consumed a day $(26,27)$ Average servings were $30 \mathrm{~g}$ for nuts, $50 \mathrm{~g}$ for dried fruit, $150 \mathrm{~g}$ for fresh fruit, $200 \mathrm{~g}$ for vegetables, and 50-200 $\mathrm{g}$ for whole grains and legumes.

To calculate consumption in our population, DF intake in grams from each food source (fruit, vegetables, whole

Table 1 Total fibre in portions/pieces of fruit

\begin{tabular}{|c|c|c|c|}
\hline Food group & $\begin{array}{l}\text { Dietary fibre } \\
(\mathrm{g}) / 100 \mathrm{~g}\end{array}$ & $\begin{array}{c}\text { Portions/pieces } \\
\text { (g) }\end{array}$ & $\begin{array}{c}\text { Total fibre } \\
\text { (g) }\end{array}$ \\
\hline \multicolumn{4}{|l|}{ Fruit } \\
\hline Apricot & 2.00 & 150 & 3.00 \\
\hline Banana (peeled) & 2.60 & 150 & 3.90 \\
\hline Grapes & 0.90 & 150 & 1.80 \\
\hline Kiwi & 3.00 & 150 & 4.50 \\
\hline Lemon & 2.80 & 150 & 4.20 \\
\hline Nectarine & 1.70 & 150 & 2.55 \\
\hline Peach & 1.50 & 150 & 2.25 \\
\hline Pear & 3.10 & 150 & 4.65 \\
\hline Plum & 1.40 & 150 & 2.10 \\
\hline Pineapple & 1.40 & 150 & 2.10 \\
\hline Apple (with skin) & 2.40 & 150 & 3.60 \\
\hline Average for fruit & & & 3.15 \\
\hline \multicolumn{4}{|l|}{ Dried fruit } \\
\hline Almond & 12.5 & 30 & 3.75 \\
\hline Hazelnut & 9.70 & 30 & 2.91 \\
\hline Pistachio & 10.60 & 30 & 3.18 \\
\hline Walnut & 6.70 & 30 & 2.01 \\
\hline Peanut & 8.00 & 30 & 2.40 \\
\hline Dried Apricot & 7.70 & 50 & 3.83 \\
\hline Dried cranberries & 5.00 & 50 & 2.50 \\
\hline Average for dried fruit & & & 2.94 \\
\hline Conversion factor for fruit & & & 3.05 \\
\hline
\end{tabular}

The amount of fibre (in g) in individual foods was taken from (34) and the usual portion /meal serving size (in g) was taken from $(23,25)$ 
Table 2 Total fibre content in portion of vegetables

\begin{tabular}{lccc} 
Food group & $\begin{array}{c}\text { Dietary fibre } \\
(\mathbf{g}) / \mathbf{1 0 0 g}\end{array}$ & $\begin{array}{c}\text { Meal serving } \\
(\mathbf{g})\end{array}$ & $\begin{array}{c}\text { Total fibre } \\
(\mathbf{g})\end{array}$ \\
\hline Vegetables & & & 200 \\
\hline Cabbage & 2.50 & 200 & 5.00 \\
\hline Broccoli & 3.30 & 200 & 6.60 \\
\hline Corn & 2.40 & 200 & 4.80 \\
\hline Carrot & 2.80 & 200 & 5.60 \\
\hline Cauliflower & 2.00 & 200 & 4.00 \\
\hline Mangel/spinach & 1.60 & 200 & 3.20 \\
\hline Lettuce & 1.90 & 200 & 3.80 \\
\hline Pepper & 1.70 & 200 & 3.40 \\
\hline Potatoes & 2.50 & 200 & 5.00 \\
\hline Zucchini & 1.00 & 200 & 2.00 \\
\hline Tomato & 1.20 & & 2.40 \\
\hline Average for vegetables & & & 4.16 \\
\hline Conversion factor for vegetables & & & 4.16 \\
\hline
\end{tabular}

The amount of fibre (in g) in individual foods was taken from (34) and the usual portion /meal serving size (in g) was taken from $(23,25)$

Table 3 Total fibre content in portions of whole cereals and legumes

\begin{tabular}{lccc} 
Food group & $\begin{array}{c}\text { Dietary fibre } \\
(\mathbf{g}) / \mathbf{1 0 0}\end{array}$ & $\begin{array}{c}\text { Meal serving } \\
(\mathbf{g})\end{array}$ & $\begin{array}{c}\text { Total fibre } \\
(\mathbf{g})\end{array}$ \\
\hline Cereals & & 50 & 1.08 \\
\hline Cornflakes & 3.60 & 200 & 3.60 \\
\hline Brown rice & 1.80 & 50 & 3.40 \\
\hline Wholemeal bread & 6.80 & 50 & 5.85 \\
\hline Whole breakfast cereals & 11.70 & 50 & 5.30 \\
\hline Oatmeal (uncooked) & 10.60 & 200 & 3.40 \\
\hline Oatmeal (cooked) & 1.70 & 200 & 5.60 \\
\hline Quinoa & 2.80 & 200 & 20.00 \\
\hline Buckwheat & 10.00 & 200 & 13.8 \\
\hline Corn flour/polenta & 6.90 & & 6.89 \\
\hline Average for cereals & & & 18.30 \\
\hline Beans & 12.20 & 150 & 16.20 \\
\hline Chickpeas & 10.80 & 150 & 3.00 \\
\hline Lens & 2.00 & 150 & 25.50 \\
\hline Beans (cut green) & 17.00 & 150 & 3.90 \\
\hline Beans dried & 2.60 & 150 & 13.38 \\
\hline Peas (row) & & & 10.14 \\
\hline Average for beans & & & \\
\hline Conversion factor for whole cereals and legumes & & & \\
\hline The & & & \\
\hline
\end{tabular}

The amount of fibre (in g) in individual foods was taken from (34) and the usual portion /meal serving size (in g) was taken from $(23,25)$

grain, and legumes) and total fibre intake we relied on the mathematical models described in detail by Tarcea et al. (28).

Conversion factors needed to calculate TFI were obtained as follows: we multiplied DF content of each item [available in reference (21)] on the list of top-selling produce (dried fruit included) with the weight of each serving/portion/piece to obtain total fibre content per serving/portion/piece. Then we averaged total fibre of all food items in a group (Tables 1-3). These averages served as conversion factors to calculate DF intake for each food group. Intake reported in the questionnaire was then multiplied with the conversion factor of 3.05 for fruit, 4.16 for vegetables, and 10.14 for cereals and legumes to obtain TFI. 


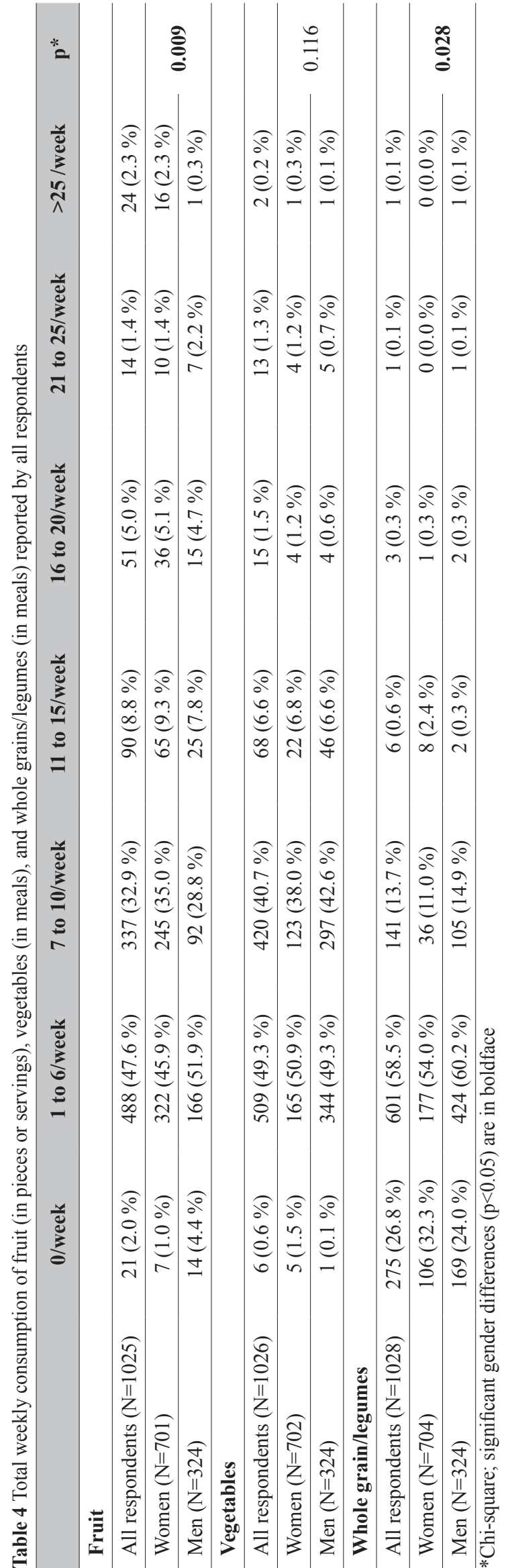

\section{Statistical analysis}

The collected data were processed with SPSS Statistics for Windows, version 22.0 (IBM, Armonk, NY, USA). Normality of distribution was tested with the KolmogorovSmirnov test. For descriptive statistic we calculated medians and interquartile ranges for numeric variables as well as absolute numbers and percentages for categorical variables, because data distribution was not normal.

For the analysis of differences between men and women in total weekly consumption of fruit (in pieces or servings), vegetables (in meals), and whole grains/legumes (in meals) and for the TFI we used the chi-squared test (for categorical variables) and Mann-Whitney U test (for numerical variables). Statistical significance was set at $\mathrm{p}<0.05$.

\section{RESULTS}

Of the 1,034 respondents (708 women and 326 men; $68.5 \%$ and $31.5 \%$, respectively), $593(57.7 \%$ ) had secondary school education, 407 (39.6\%) university education, and only 27 (2.6\%) had primary school education. Most were urban residents (774; $76.3 \%$ ). Age distribution (median 38 years; interquartile range 20 years) was relatively uniform, with $14 \%$ younger than 24 years and $36 \%$ older than 45 . The median age of women was 38 years (interquartile range 20) and of men 39 years (interquartile range 21).

Table 4 shows the distribution of respondents considering the number of servings/pieces of fruit, meals of vegetables, or meals of cereals/legumes per week. 1025 returned valid FFQ for fruit, 1026 for vegetables, and 1028 for whole grains and legumes (Table 4). Our respondents consumed 6,672 meals of vegetables, 8,167 servings/pieces of fruit, and 2,887 meals of whole grains and legumes a week. Per person it breaks down to 1.18 pieces (about 1 serving) of fruit, 0.93 meals (about 2 servings) of vegetables and legumes, and 0.40 meals (about 1 serving) of cereals and legumes a day. Only $0.2 \%$ of respondents consumed the recommended 3-5 servings of whole grain cereals and legumes per person per week (Table 4). According to our estimations, adult Croatian (Dalmatian) individual consumes about $120 \mathrm{~g}$ of fruit, $185 \mathrm{~g}$ of vegetables, and $22 \mathrm{~g}$ of whole cereals and/or legumes per day.

Table 5 shows the results of dietary fibre intake based on food consumption data from the first stage of the study, the data obtained from shopping centres about top-selling items in our food groups, and conversion factors calculated as described in the Methods section. The TFI for mixed Croatian adult population was $11.41 \mathrm{~g}(11.77 \mathrm{~g}$ and $10.58 \mathrm{~g}$ for women and men, respectively). According to surveys from different European countries $(3,29,30)$, TFI from these main fibre sources accounts for $80 \%$ of daily TFI from all sources (which includes processed food and other sources). 


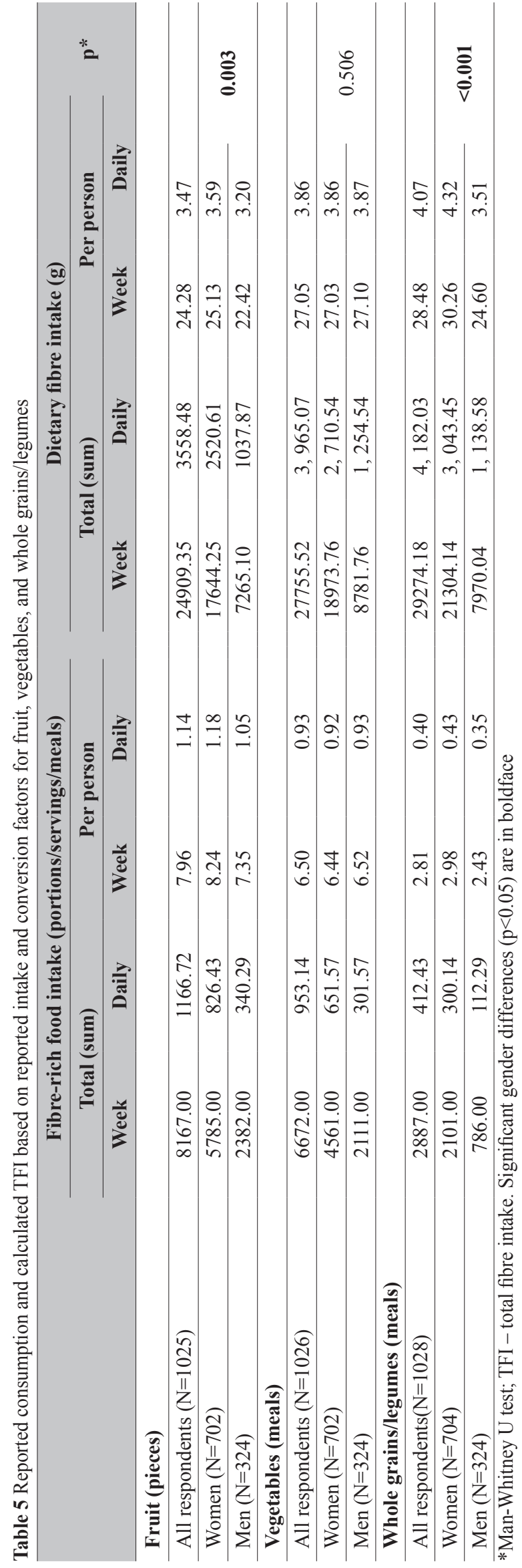

Women consumed significantly more fruit and whole grains/legumes than men (1.18 vs 1.05 servings/pieces of fruit and 0.43 vs 0.35 meals of whole grains and legumes, respectively) per day. As for vegetables, men consumed slightly more than women ( 0.93 vs 0.92 meals per day).

\section{DISCUSSION}

Our findings have confirmed our suspicion that Croatian Dalmatian population consumes fibre and fibre-rich foods far below recommended levels, just like many other Western nations $(3,31)$. An earlier research in Croatia (32) reported average daily intake of dietary fibre of $21 \mathrm{~g}$ (recommendations range between 21 and $38 \mathrm{~g}$ a day), and $45 \%$ of the intake referred to cereals. However, the relevance of these earlier findings is limited, as the study included a very small sample. Our current findings show that most respondents do not have a sufficient whole grain cereal and therefore fibre intake. Similarly low (about $30 \%$ of the recommended) intakes have been reported by the US Institute of Medicine (14) and the Dietary Guidelines for Americans (7). These two sources also reported that men consumed more cereals than women due to larger bodies and greater need, which contradicts our findings.

What we find discouraging is that $26.8 \%$ of our respondents reported never consuming whole cereals and legumes. This may reflect poor consumer awareness of the health benefits of whole grains $(4,5,18,33,34)$.

In contrast, only $2.0 \%$ and $0.6 \%$ of our respondents reported never consuming fruit and vegetables, respectively. This may be related to the fact that more than $90 \%$ of our respondents live in the coastal area with a predominant Mediterranean diet, rich in fruit and vegetables (20). However, Mediterranean diet is also rich in cereals and legumes, yet our findings show a very low intake of these. Even the consumption of vegetables and fruit in our adult sample is below the recommended amounts of $200 \mathrm{~g}$ for vegetables and $200 \mathrm{~g}$ for fruit (13).

Beside the expected difference in the consumption of fruit and whole grain cereals between women and men, our study unexpectedly showed no such gender difference for vegetables, which is in contrast with previous studies (35, 36).

In terms of total fibre intake of $11.4 \mathrm{~g}$ in our sample, it is less than half the recommended intake but similar to many European countries (28-30, 32, 37-41). As expected from earlier research, it is also lower in men than women. Considering that fruit, vegetables, whole grain cereals, and legumes make $80 \%$ of the TFI (the remaining $20 \%$ is from processed food and other sources) $(3,29,30)$, the contribution from fruit and vegetables in our study is $50 \%$ and from whole cereals and legumes $30 \%$. This latter contribution of only $30 \%$ from whole grains and legumes is quite discouraging, as it is even lower than in other 
European countries (with more than $40 \%$ contribution) $(37$, $38,41,42)$.

Our findings, however, should be taken with some reserve due to the following limitations: our participants took the FFQ only once and may have under- or overreported food intake. Fibre intake may also have been underestimated in calculations, as current conversion factors and nutrition databases may not include all fibre sources and analytical results for whole grain, fruit, and vegetables consumed in Croatia.

\section{CONCLUSION}

This study gives us a broad idea of the poor dietary habits of Croatian, more specifically Dalmatian population when it comes to fibre-rich foods. It also points to similar deficits in diet of many Western countries and to issues that are deeply rooted in their economies. Raising awareness may sort part of the problem, but unless these deep economic issues are resolved, including high prices of fibre-rich food compared to processed and fibre-poor food and meat, we are afraid health risks related to poor dietary habits will continue. Further research in our country should strive to gain a more accurate and detailed insight into TFI through longitudinal studies of broader samples, using more precise tools.

\section{Acknowledgement}

This work was prepared in the ambit of the multinational project (PROJ/CI\&DETS/2014/0001) of the CI\&DETS Research Centre (IPV, Viseu, Portugal).

\section{Statements of ethical approval}

Ethical approval was granted by the Human Research Ethics Committee of General Hospital Zadar (No. 01-178$3 / 15)$. The research conformed to the provisions of the 2000 World Medical Association Declaration of Helsinki: ethical considerations for medical research involving human subjects.

\section{Competing interests}

None to declare.

\section{REFERENCES}

1. Liu RH. Potential synergy of phytochemicals in cancer prevention: mechanism of action. J Nutr 2004;134(Suppl 12):3479S-85S. doi: 10.1093/jn/134.12.3479S

2. Willett WC. Balancing life-style and genomics research for disease prevention. Science 2002;296:695-8. doi: 10.1126 science. 1071055

3. Stephen AM, Champ MM-J, Cloran SJ, Fleith M, van Lieshout L, Mejborn H, Burley VJ. Dietary fibre in Europe: current state of knowledge on definitions, sources, recommendations, intakes and relationships to health. Nutr Res Rev 2017;30:149-90. doi: 10.1017/S095442241700004X

4. Guiné RPF, Ferreira M, Correia P, Duarte J, Leal M, Rumbak I, Colić Barić I, Komes D, Satalić Z, Matek Sarić M, Tarcea M, Fazakas Z, Jovanoska D, Vanevski D, Vittadini E, Pellegrini N, Szücs V, Harangozó J, EL-Kenawy A, ELShenawy O, Yalçın E, Kösemeci C, Klava D, Straumite E. Knowledge about dietary fibre: a fibre study framework. Int J Food Sci Nutr 2016;67:707-14. doi: 10.1080/09637486.2016.1191443

5. Guiné RPF, Duarte J, Ferreira M, Correia P, Leal M, Rumbak I, Colić Barić I, Komes D, Satalić Z, Matek Sarić M, Tarcea M, Fazakas Z, Jovanoska D, Vanevski D, Vittadini E, Pellegrini N, Szücs V, Harangozó J, El-Kenawy A, ElShenawy O, Yalçın E, Kösemeci C, Klava D, Straumite E. Knowledge about dietary fibres (KADF): development and validation of an evaluation instrument through structural equation modelling (SEM). Public Health 2016;138:108-18. doi: 10.1016/j.puhe.2016.03.031

6. Carvalho A, Portela M, Sousa FC, Farias DF, Feitosa J. Physiological and physico-chemical characterization of dietary fibre from the green seaweed Ulva fasciata Delile. Braz J Biol 2009;69:969-77. doi: 10.1590/s151969842009000400028

7. USDA-Food \& Nutrition Service. Center for Nutrition Policy and Promotion (CNPP) | USDA-FNS [displayed 26 May 2019]. Available at https://www.fns.usda.gov/cnpp/centernutrition-policy-and-promotion

8. Food and Drug Administration. Revision of the Nutrition and Supplement Facts Label, 2016.

9. Jakobek L, Matić P. Non-covalent dietary fiber - Polyphenol interactions and their influence on polyphenol bioaccessibility. Trends Food Sci Technol 2019;83:235-47. doi: 10.1016/j. tifs.2018.11.024

10. European Commission's science and knowledge service. Dietary Fibre | EU Science Hub [displayed 11 May 2019]. Available at https://ec.europa.eu/jrc/en/health-knowledgegateway/promotion-prevention/nutrition/fibre

11. Qi X, Tester RF. Utilisation of dietary fibre (non-starch polysaccharide and resistant starch) molecules for diarrhoea therapy: A mini-review. Int J Biol Macromol 2019;122:572_ 7. doi: 10.1016/j.ijbiomac.2018.10.195

12. Zhang H, Wang H, Cao X, Wang J. Preparation and modification of high dietary fiber flour: A review. Food Res Int 2018;113:24-35. doi: 10.1016/j.foodres.2018.06.068

13. European Commission's science and knowledge service. Fruit and Vegetables | EU Science Hub [displayed 11 May 2019]. Available at https://ec.europa.eu/jrc/en/healthknowledge-gateway/promotion-prevention/nutrition/fruitvegetables

14. Institute of Medicine. Dietary Reference Intakes for Energy, Carbohydrate, Fiber, Fat, Fatty Acids, Cholesterol, Protein, and Amino Acids. Washington (DC): The National Academies Press; 2005. ISBN: 978-0-309-08525-0

15. World Health Organization. Global Action Plan for the Prevention and Control of Noncommunicable Diseases 2013-2020. [displayed 11 June 2019]. Available at http:// apps.who.int/iris/bitstream/10665/94384/1/9789241506236 eng.pdf

16. European Food Safety Authority. DRV Finder [displayed 11 May 2020]. Available at https://www.efsa.europa.eu/en/ interactive-pages/drvs 
17. Whole Grains Council. U.S. Dietary Guidelines and WG [displayed 3 February 2019]. Available at https:// wholegrainscouncil.org/whole-grains-101/how-muchenough/us-dietary-guidelines-and-wg

18. Ljubičić M, Matek Saric M, Rumbak I, Colić Barić I, Komes D, Šatalić Z, Guiné RPF. Knowledge about dietary fibre and its health benefits: A cross-sectional survey of 2536 residents from across Croatia. Med Hypotheses 2017;105:25-31. doi: 10.1016/j.mehy.2017.06.019

19. Healey G, Brough L, Murphy R, Hedderley D, Butts C, Coad $\mathrm{J}$. Validity and reproducibility of a habitual dietary fibre intake short food frequency questionnaire. Nutrients 2016;8:558. doi: 10.3390/nu8090558

20. Ljubičić M, Matek Sarić M, Colić Barić I, Rumbak I, Komes D, Šatalić Z, Guiné RPF. Consumer knowledge and attitudes toward healthy eating in Croatia: a cross-sectional study. Arh Hig Rada Toksikol 2017;68:153-8. doi: 10.1515/aiht-201768-2939

21. United States of Department of Argiculture. USDA National Nutrient Database for Standard Reference : USDA ARS [displayed 3 February 2019]. Available at https://www.ars. usda.gov/northeast-area/beltsville-md-bhnrc/beltsvillehuman-nutrition-research-center/nutrient-data-laboratory/ docs/usda-national-nutrient-database-for-standard-reference/

22. Tal A, Niemann S, Wansink B. Depicted serving size: cereal packaging pictures exaggerate serving sizes and promote overserving. BMC Public Health 2017;17:169. doi: 10.1186/ s12889-017-4082-5

23. Pereira JL, Félix PV, Mattei J, Fisberg RM. Differences over 12 years in food portion size and association with excess body weight in the city of São Paulo, Brazil. Nutrients 2018;10:696. doi: 10.3390/nu10060696

24. Heart Foundation. Fruit and vegetable consumption statistics [displayed 3 February 2019]. Available at https://www. heartfoundation.org.au/about-us/what-we-do/heart-diseasein-australia/fruit-and-vegetable-consumption-statistics

25. Fisher JO, Goran MI, Rowe S, Hetherington MM. Forefronts in portion size. An overview and synthesis of a roundtable discussion. Appetite 2015;88:1-4. doi: 10.1016/j. appet.2014.11.025

26. Longo VD, Mattson MP. Fasting: Molecular mechanisms and clinical applications. Cell Metab 2014;19:181-92. doi: 10.1016/j.cmet.2013.12.008

27. Casazza K, Fontaine KR, Astrup A, Birch LL, Brown AW, Bohan Brown MM, Durant N, Dutton G, Foster EM, Heymsfield SB, McIver K, Mehta T, Menachemi N, Newby PK, Pate R, Rolls BJ, Sen B, Smith DL, Thomas DM, Allison DB. Myths, presumptions, and facts about obesity. N Engl J Med 2013;368:446-54. doi: 10.1056/NEJMsa1208051

28. Tarcea M, Fazakas Z, Szucs V, Kovacs Z, Nagy EN, Olah P, Tilinca M, Guiné R. Mean dietary fiber intake of Romanian adults results of a survey questionnaire. Rev Chim (Bucharest) 2017;68:2083-7.

29. Lin Y, Huybrechts I, Vandevijvere S, Bolca S, De Keyzer W, De Vriese S, Polet A, De Neve M, Van Oyen H, Van Camp J, De Backer G, De Henauw S. Fibre intake among the Belgian population by sex-age and sex-education groups and its association with BMI and waist circumference. Br J Nutr 2011;105:1692-703. doi: 10.1017/S0007114510005088

30. Agence Française de Sécurité Sanitaire des Aliments. Avis de l'Agence française de sécurité sanitaire des aliments relatif à l'évaluation de la demande de mise sur le marché d'un nouvel ingrédient alimentaire, la gomme de guar, no. 2009SA-0214 [Opinion of the French Food Safety Agency on the assessment of the application for the placing on the market of a novel food ingredient, guar gum, no. 2009-SA-0214, in French], 2009 [displayed 3 February 2019]. Available at https://www.anses.fr/fr/system/files/NUT2009sa0214.pdf

31. Mann KD, Pearce MS, McKevith B, Thielecke F, Seal CJ. Low whole grain intake in the UK: results from the National Diet and Nutrition Survey Rolling Programme 2008-11. Br J Nutr 2015;113:1643-51. doi: 10.1017/S0007114515000422

32. Perl Pirički A, Mandić ML, Kenjerić D, Primorac L. Food patterns in intake of dietary fibre in small group of Croatian adults. Croat J Food Sci Technol 2009;1:8-14.

33. Guiné R, Duarte J, Ferreira M, Correia P, Leal M, Rumbak I, Colic Baric I, Komes D, Satalic Z, Matek Saric M, Tarcea M, Fazakas Z, Jovanoska D, Vanevski D, Vittadini E, Pellegrini N, Szucs V, Harangozó J, EL-Kenawy A, ELShenawy O, Yalçin E, Kösemeci C, Klava D, Straumite E. Benefits of dietary fibre to human health: study from a multicountry platform. Nutr Food Sci 2017;47:688-99. doi: 10.1108/NFS-11-2016-0165

34. Ferreira M, Guiné PFR, Duarte J, Correia P, Leal M, Rumbak I, Barić Colić I, Komes D, Šatalić Z, Matek Sarić M, Tarcea M, Fazakas Z, Jovanoska D, Vanevski D, Vittadini E, Pellegrini N, Szűcs V, Harangozó J, El-Kenawy A, ElShenawy O, Yalçınu E, Kösemeci C, Klava D, Straumite E. Sources of information about dietary fibre: a cross-country survey. In: Bekirogullari Z, Minas MY, Thambusamy RX, editors. The European Proceedings of Social and Behavioural Sciences EpSBS, ICEEPSY 2016; 10-15 October 2016. Vol. XVI. Future Acad: 2016. p. 7-17.

35. Baker AH, Wardle J. Sex differences in fruit and vegetable intake in older adults. Appetite. 2003;40(3):269-75. doi: 10.1016/S0195-6663(03)00014-X

36. Pan WH, Yeh NH, Yang RY, Lin WH, Wu WC, Yeh WT, Sung MK, Lee HS, Chang SJ, Huang CJ, Lin BF, Chiang MT. Vegetable, fruit, and phytonutrient consumption patterns in Taiwan. J Food Drug Anal 2018;26:145-53. doi: 10.1016/j. jfda.2016.12.015

37. Prynne CJ, McCarron A, Wadsworth MEJ, Stephen AM. Dietary fibre and phytate - a balancing act: results from three time points in a British Birth Cohort. Br J Nutr 2010;103:274 80. doi: $10.1017 / \mathrm{S} 0007114509991644$

38. Van Rossum CTM, Fransen HP, Verkaik-Kloosterman J, Buurma-Rethans EJM, Ocké MC. Dutch National Food Consumption Survey 2007-2010: Diet of children and adults aged 7 to 69 years, 2007 [displayed 3 February 2019]. Available at https://www.rivm.nl/publicaties/dutch-nationalfood-consumption-survey-2007-2010-diet-of-children-andadults-aged-7-to

39. Pedersen AN, Fagt S, Velsing Groth M, Christensen T, BiltoftJensen A, Matthiessen J, Andersen NL, Kørup K, Hartkopp H, Ygil KH, Hinsch H-J, Saxholt E, Trolle E. Danskernes kostvaner 2003-2008 [Dietary habits in Denmark 20032008, in Danish] [displayed 12 June 2020]. Available at https://www.food.dtu.dk/english/-/media/Institutter/ Foedevareinstituttet/Publikationer/Pub-2010/Danskerneskostvaner-2003-2008.ash $\mathrm{x}$ la $=\mathrm{da} \& \mathrm{hash}=\mathrm{C} 8 \mathrm{~F} 5 \mathrm{~F} 1$ 6BB88D2762D0F38CBDAE82A7BA056A252C

40. Bates B, Lennox A, Prentice A, Bates CJ, Page P, Nicholson S, Swan G, editors. National Diet and Nutrition Survey: Results from Years 1, 2, 3 and 4 (combined) of the Rolling 
Programme (2008/2009-2011/2012): a Survey Carried Out on Behalf of Public Health England and the Food Standards Agency. London: Public Health England; 2014.

41. Amcoff E, Edberg A, Enghart Barbieri H, Karin Lindroos A, Nälsén C, Pearson och M, Warensjö Lemming E. Livsmedelsoch näringsintag bland vuxna i Sveriet, metodrapport, Riksmaten vuxna 2010-11, 2014 [Food and nutrient intake among adults in Sweden, in Swedish] [displayed 3 February
2019]. Available at https://www.livsmedelsverket.se/ globalassets/publikationsdatabas/rapporter/2014/riksmatenvuxna-2010-11-metodrapport--rapport-8---2014.pdf

42. Serra-Majem L, Ribas-Barba L, Salvador G, Jover L, Raidó B, Ngo J, Plasencia A. Trends in energy and nutrient intake and risk of inadequate intakes in Catalonia, Spain (19922003). Public Health Nutr 2007;10:1354-67. doi: 10.1017/ S1368980007000961

\section{Doprinos voća, povrća, cjelovitih žitarica i mahunarki ukupnom unosu prehrambenih vlakana u odrasle populacije iz Dalmacije}

Postoje uvjerljivi dokazi da su voće, povrće, cjelovite žitarice i mahunarke glavni izvori prehrambenih vlakana iz hrane, tj. čine oko $80 \%$ ukupnog unosa prehrambenih vlakana i mogu potencijalno pomoći u prevenciji mnogih bolesti. Cilj naše studije bio je procijeniti ukupni unos vlakana konzumacijom hrane koja predstavlja glavne izvore prehrambenih vlakana. Dio podataka objavljen je u našoj ranijoj studiji za odraslu hrvatsku populaciju. Konkretna analiza podataka uključivala je uzorak od 1.034 odrasla ispitanika u Dalmaciji u Hrvatskoj koji su odgovorili na validirani upitnik o frekvenciji unosa hrane bogate vlaknima između listopada 2014. i ožujka 2015. Također, analizirali smo i uspostavili popis najčešće kupljenog voća, povrća, cjelovitih žitarica i mahunarki u trima trgovačkim centrima na području grada Zadra (hrvatska obala). Na osnovi dobivenih podataka za svaki smo pojedinačni proizvod izračunali čimbenik pretvorbe te ga procijenili za pojedinu skupinu hrane: voće, povrće, cjelovite žitarice i mahunarke. Dobivene čimbenike pretvorbe te podatke iz ankete upotrijebili smo za izračun ukupnog unosa vlakana (TFI) za našu ispitivanu populaciju, i on je iznosio 11,4 g po osobi dnevno, što je samo polovica preporučenih prehrambenih potreba. U prosjeku su ispitanici izvijestili da konzumiraju jedan komad voća i jedan obrok povrća dnevno, što je manje od polovine dnevne preporuke za oba izvora. Četvrtina ispitanika (25,8 \%) izvijestila je da uopće ne konzumira cjelovite žitarice, a njih samo 0,2\% konzumiralo je preporučenih 3-5 obroka cjelovitih žitarica ili mahunarki dnevno. Također smo uočili značajno veću konzumaciju voća i cjelovitih žitarica/mahunarki kod žena u odnosu na muškarce. Naša otkrića upozoravaju na nedovoljan unos prehrambenih vlakana u odrasloj populaciji u Dalmaciji u Hrvatskoj, što je slično nalazima iz drugih zapadnih zemalja te upućuje na duboko ukorijenjene probleme u tim gospodarstvima. Međutim, naša otkrića mogu biti ili precijenjena ili podcijenjena, stoga ih je potrebno potvrditi novim longitudinalnim istraživanjima na širem uzorku, koristeći se preciznijim alatima.

KLJUČNE RIJEČI: faktor pretvorbe; hrana bogata vlaknima; prehrambena vlakna; preporučene prehrambene potrebe; 